\title{
PENGARUH PEMBIAYAAN MURABAHAH TERHADAP KESEJAHTERAAN NASABAH
}

\author{
Ali Nur Ahmad \\ Siti Nurrohmah \\ STAI PELITA BANGSA \\ ali.nurahmad@pelitabangsa.ac.id
}

\begin{abstract}
ABSTRAK
Penelitian ini bertujuan untuk menemukan apakah pembiayaan murabahah berpengaruh pada kesejahteraan nasabah. Hasil penelitian menunjukkan bahwa pembiayaan murabahah hanya mempengaruhi $0,8 \%$ terhadap kesejahteraan nasabah dan 99,2\% dipengaruhi dari faktor lain. Pembiayaan murabahah yang diberikan tidak mempengaruhi kesejahteraan nasabah dikarenakan adanya faktor penyalahgunaan akad yaitu nasabah menggunakan pembiayaan murabahah tidak untuk modal usaha melainkan untuk memenuhi kebutuhan sehari-hari seperti biaya sekolah, belanja dapur dan kebutuhan lainya. Penyalahgunaan akad berpengaruh negatif terhadap pembiayaan murabahah yang diberikan. Sehingga pembiayaan murabahah tidak dapat mempengaruhi kesejahteraan nasabah.
\end{abstract}

Kata kunci: Pembiayaan murabahah; kesejahteraan nasabah.

\section{ABSTRACT}

This study aims to find whether murabahah financing affects the welfare of customers. Result of research indicate that murabahah financing only influence $0,8 \%$ to customer's welfare and $99,2 \%$ influenced from other factor. Murabahah financing that is given does not affect the welfare of the customers due to the misuse of the contract, the customer uses murabahah financing not for business capital but to meet daily needs such as school fees, kitchen expenses and other necessities. Misuse of the contract negatively affects the murabahah financing given. Thus murabahah financing can not affect the welfare of customers.

Key words: Murabahah financing; customers' welfare.

\section{PENDAHULUAN}

Perbankan syariah di Indonesia mulai berdiri tahun 1992, dengan salah satu motifnya antara lain adalah membangun ekonomi umat islam yang sekian lama terpinggirkan. Tampaknya fenomena domestik ini membuat orang salah menduga bahwa bank syariah itu hanya untuk orang islam dan merupakan bank sosial. Padahal bank syariah itu umumnya bank komersial, melayani siapa saja dan dilaksanakan oleh siapa saja, baik muslim maupun tidak (Hakim, 2011)

Perkembangan perbankan syariah yang begitu cepat telah memacu perkembangan produk layanan dan jasa agar dapat melayani keperluan masyarakat. Sebelum tahun 1997, produk perbankan syariah terbatas kepada giro, tabungan dan deposito pada sisi penghimpunan dana, sedangkan pada 
sisi pembiayaan hanya dua produk yang sering digunakan yaitu bay bithaman 'ajil dan murabahah. Yang pertama digunakan untuk pembiayaan investasi, sedangkan yang kedua diterapkan untuk membiayai modal kerja. Meskipun ada produk lain, seperti mudharabah dan musyarakah, namun kedua produk ini jarang digunakan.

Dari sekian produk yang dikembangkan perbankan syariah, sampai saat ini murabahah adalah produk yang mendominasi portofolio hampir seluruh pembiayaan. Ada berbagai alasan mengapa murabahah lebih sering digunakan ketimbang produk lainnya. Pertama, kemiripan dengan kredit yang biasa dilakukan dalam perbankan. Para praktisi hanya perlu menyesuaikan praktik kredit biasa dengan syarat-syarat yang diperlukan dalam murabahah, atau sebaliknya. Kedua, nasabah mudah mengetahui kewajiban yang harus ia bayarkan tiap bulan/minggu, bahkan dapat mengetahui berapa diskon yang akan didapatkan apabila pelunasanya dipercepat. ${ }^{1}$

Pembiayaan murabahah itu sendiri merupakan pembiayaan berupa talangan dana yang dibutuhkan nasabah untuk membeli suatu barang/jasa dengan kewajiban mengembalikan talangan dana tersebut seluruhnya pada waktu jatuh tempo. Bank memperoleh margin keuntungan dari transaksi jual beli antara bank dengan pemasok dan antara bank dengan nasabah. ${ }^{2}$

Murabahah dapat digunakan untuk akad pembiayaan modal kerja atau investasi kepada pengusaha. Bank bertindak sebagai pembeli yang membeli barang dari penjual barang dan sekaligus bertindak sebagai penjual barang tersebut kepada nasabah. Bank mengambil margin dari transaksi tersebut. Namun, dalam praktiknya bank menggunakan akad wakalah (perwakilan) untuk mewakilkan pembelian kepada nasabah itu sendiri. ${ }^{3}$

Pembiayaan murabahah yang diberikan oleh perbankan syariah merupakan pemberian modal usaha kepada nasabah prasejahtera untuk mengembangkan usahanya baik nasabah beragama islam maupun non islam dengan akad yang telah disepakati bersama. Salah satu perbankan yang menerapkan akad murabahah tersebut adalah BTPN Syariah.

Sesuai akad pembiayaan murabahah yang diterapkan di BTPN Syariah hanya diberikan untuk usaha yang halal dan sesuai syariah islam. Selain itu, pembiayaan murabahah juga memiliki tujuan yaitu membantu perekonomian nasabah dan meningkatkan pendapatanya serta berusaha mengembalikan lagi sistem islam dalam setiap transaksi muamalah yang jauh dari bunga dan riba.

Seperti yang tercantum dalam surat Al Baqarah ayat 278- 279

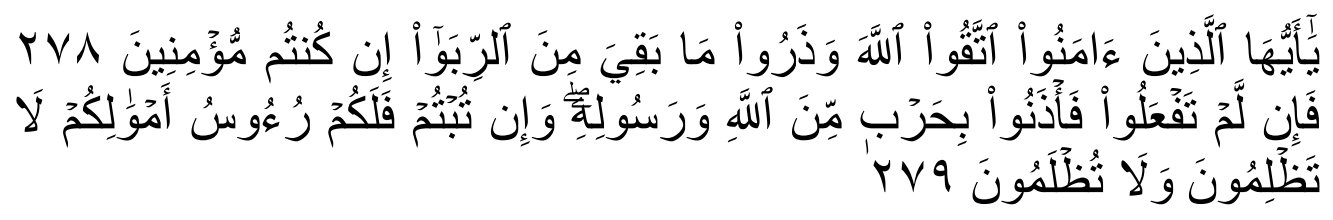

1 ibid, h. 71-72

${ }^{2}$ Karnaen A. Perwataatmadja dan Hendri Tanjung, Bank Syariah ;Teori Praktek dan

Penerapanya, Jakarta: Celestial Publising, 2007, h .77

${ }^{3}$ Chandra Natadipurba, Ekonomi Islam 101, Bandung : PT Mobildelta Indonesia, 2016, h.292 
"Hai orang-orang yang beriman, bertakwalah kepada Allah dan tinggalkan sisa riba (yang belum dipungut) jika kamu orang-orang yang beriman."( QS. Al Baqarah ayat 278)

"Maka jika kamu tidak mengerjakan (meninggalkan sisa riba), maka ketahuilah, bahwa Allah dan Rasul-Nya akan memerangimu. Dan jika kamu bertaubat (dari pengambilan riba), maka bagimu pokok hartamu; kamu tidak menganiaya dan tidak (pula) dianiaya."( QS. Al Baqarah ayat 279)

Dengan demikian, cukup jelas bahwa bunga bank termasuk praktik riba, karena bunganya disyaratkan di muka pada waktu menerima pinjaman.

Dalam memberikan pembiayaan murabahah, BTPN (Bank Tabungan Pensiunan Nasional) syariah tidak hanya terfokus kepada nasabah muslim melainkan juga memberikan pembiayaan kepada nasabah non muslim. Namun, pembiayaan murabahah tidak diberikan kepada nasabah sejahtera karena BTPN (Bank Tabungan Pensiunan Nasional) syariah hanya berfokus kepada nasabah prasejahtera untuk mengembangkan usahanya dan dalam hal ini hanya berfokus pada nasabah perempuan atau wanita Indonesia. Sedangkan tujuan utama pembiayaan adalah mensejahterakan nasabah prasejahtera menjadi sejahtera terutama kaum hawa atau ibu-ibu, agar bisa menjadi wanita mandiri dan berdayaguna.

Pertanyaan yang kemudian muncul adalah:

1. Apakah dengan pembiayaan murabahah yang diberikan BTPN Syariah dapat mensejahterakan nasabah?

2. Seberapa besarkah pengaruh pembiayaan murabahah dalam meningkatkan kesejahteraan nasabah?

Dalam penelitian ini terdapat pembatasan masalah yaitu penelitian ini hanya membahas tentang pembiayaan murabahah terhadap kesejahteraan nasabah di BTPN (Bank Tabungan Pensiunan Nasional) Syariah KFO Cikarang Barat tahun 2017.

\section{PEMBIAYAAN MURABAHAH, KESEJAHTERAAN NASABAH}

1. Pembiayaan Murabahah

1) Pengertian Pembiayaan

Pembiayaan yang artinya kepercayaan (trust) yang berarti bank menaruh kepercayaan kepada seseorang untuk melaksanakan amanah yang diberikan oleh bank selaku shahibul maal. Dana tersebut harus digunakan dengan benar, adil, dan harus disertai dengan ikatan dan syarat-syarat yang jelas serta saling menguntungkan bagi kedua belah pihak. Veithzal Rivai dan Arviyan Arifin menjelaskan, pembiayaan adalah penyediaan uang atau tagihan yang dapat dipersamakan dengan itu, berdasarkan persetujuan atau kesepakatan pinjam meminjam antara bank atau lembaga keuangan lainya dengan pihak lain yang mewajibkan pihak pinjaman untuk melunasi utangnya setelah jangka waktu tertentu dengan imbalan bagi hasil (Veithzal Rivai dan Arviyan Arifin, Islamic Banking ; Sebuah Teori, konsep, dan Aplikasi, Jakarta: Bumi Aksara, 2010 , h. 698) 
Dalam Undang-Undang Perbankan Syariah 2008 (UU RI No. 21 Tahun 2008) menyebutkan pembiayaan adalah penyediaan dana atau tagihan/piutang yang dapat dipersamakan dengan itu dalam:

a. Transaksi investasi yang didasarkan antara lain atas akad mudharabah dan musyarakah.

b. Transaksi sewa yang didasarkan antara lain atas akad ijarah atau akad ijarah dengan opsi perpindahan hak milik (ijarah muntahiya bit tamlik).

c. Transaksi jual beli yang didasarkan antara lain atas akad murabahah, salam, dan istisna.

d. Transaksi pinjaman yang didasarkan antara lain akad qard.

e. Transaksi multi jasa yang didasarkan antara lain atas akad ijarah dan kafalah.

2) Pengertian Murabahah

Secara bahasa, kata murabahah berasal dari bahasa arab dengan akar kata ribhu yang artinya "keuntungan". Sedangkan menurut istilah, menurut Lukman Hakim, murabahah merupakan akad jual beli atas barang tertentu, dimana penjual menyebutkan harga jual yang terdiri atas harga pokok barang dan tingkat keuntungan tertentu atas barang, dimana harga jual yang tersebut disetujui pembeli (Hakim, 2012).

Secara istilah, selain yang dikemukaan oleh Lukman Hakim masih banyak definisi tentang pembiayaan murabahah, diantaranya yaitu:

Menurut Syafi'i Antonio, bai' murabahah adalah jual beli barang pada harga asal dengan tambahan keuntungan yang disepakati. Dalam ba'i murabahah, penjual harus memberi tahu harga produk yang dibeli dan menentukan suatu tingkat keuntungan sebagai tambahannya.

Menurut Anwar, murabahah adalah menjual suatu barang dengan harga pokok ditambah keuntungan yang disetujui bersama untuk dibayar pada waktu yang ditentukan atau dibayar secara cicilan. $^{4}$

Sedangakan di dalam fatwa Dewan Syariah Nasional (DSN) No. 04/DSN-MUI/IV/2000, murabahah yaitu menjual suatu barang dengan menegaskan harga belinya kepada pembeli dan pembeli membayarnya dengan harga yang lebih sebagai laba (Muthahter, 2012).

Dari pengertian pembiayaan dan murabahah diatas dapat diambil kesimpulan bahwa pembiayaan murabahah adalah pemberian talangan dana oleh bank atau lembaga keuangan syariah lainnya kepada nasabah dengan kesepakatan dan persetujuan pengembalian dana tersebut dalam waktu yang telah ditentukan. Pihak bank atau lembaga keuangan lainya memperoleh imbalan dalam keuntungan atau margin yang telah disepakati sebelumnya.

${ }^{4}$ M Syafii Anwar, Alternatif Terhadap Sistem Bunga, Jurnal Ulumul Qur'an II, edisi 9 Oktober 1991, h. 13 
3) Dasar Hukum Murabahah

a. Al Qur'an Surat An- Nissa: 29

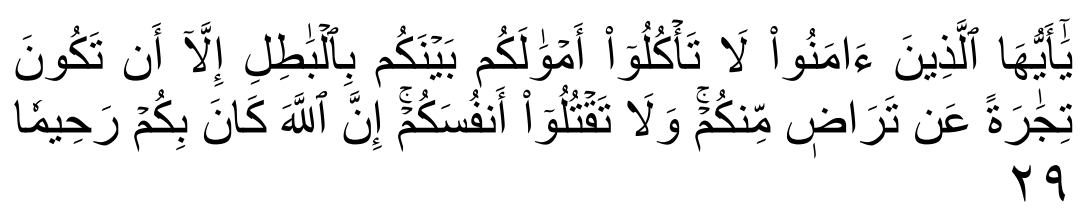

"Hai orang-orang yang beriman, janganlah kamu saling memakan harta sesamamu dengan jalan yang batil, kecuali dengan jalan perniagaan yang berlaku dengan suka sama-suka di antara kamu. Dan janganlah kamu membunuh dirimu; sesungguhnya Allah adalah Maha Penyayang kepadamu. ( Al Qur'an Surat An-Nissa : 29)

b. Al Hadists

Dari Suhaib ar-Rumi r.a. bahwa Rasulullah $S A W$ bersabda, "Tiga hal yang di dalamnya terdapat keberkahan: jual beli secara tangguh, muqaradhah (mudharabah), dan mencampur gandum dengan tepung untuk keperluan rumah bukan untuk dijual."(HR Ibnu Majah).

c. Ijma

Menurut imam Malik, murabahah itu dibolehkan (mubah) dengan berlandaskan pada orang-orang Madinah, yaitu ada konsensus pendapat di Madinah mengenai hukum tentang orang yang membeli baju disebuah kota, dan mengambilnya ke kota lain untuk menjualnya berdasarkan suatu kesepakatan berdasarkan keuntungan. Imam Syafi'i mengatakan jika seorang menunjukkan komoditas kepada seseorang dan mengatakan "kamu beli untukku, aku akan memberikan keuntungan begini, begitu", kemudian orang itu membelinya, maka transaksi itu sah. Sedangkan Marghinani seorang fiqih mazhab Hanafi membenarkan keabsahan murabahah berdasarkan kondisi penting bagi validitas penjualan di dalamnya. Demikian pula Nawawi dari mazhab Syafi'i, secara sederhana mengemukakan bahwa penjualan murabahah sah menurut hukum tanpa bantahan.

4) Fatwah DSN Tentang Ketentuan Murabahah

Pembiayaan telah diatur dalam fatwa DSN No 04/DSNMUI/IV/2000. Dalam fatwa tersebut disebutkan ketentuan umum mengenai murabahah, yaitu sebagai berikut:

a. Bank dan nasabah harus melakukan akad murabahah yang bebas riba.

b. Barang yang diperjual belikan tidak diharamkan oleh syari'at islam.

c. Bank membiayai sebagian atau seluruh harga pembelian barang yang telah disepakati kualifikasinya.

d. Bank membeli barang yang diperlukan nasabah atas nama bank sendiri, dan pembelian ini harus sah dan bebas riba. 
e. Bank harus menyampaikan semua hal yang berkaitan dengan pembelian, misalnya jika pembelian dilakukan secara utang.

f. Bank kemudian menjual barang tersebut kepada nasabah dengan harga jual senilai harga plus keuntungannya. Dalam kaitan ini bank harus memberitahu secara jujur harga pokok barang kepada nasabah berikut biaya yang diperlukan.

g. Nasabah membayar harga barang yang telah disepakati tersebut pada jangka waktu tertentu yang telah disepakati.

h. Untuk mencegah terjadinya penyalahgunaan atau kerusakan akad tersebut, pihak bank dapat mengadakan perjanjian khusus dengan nasabah.

i. Jika bank hendak mewakilkan kepada nasabah untuk membeli barang kepada pihak ketiga, akad jual beli murabahah harus dilakukan setelah barang, secara prinsip menjadi milik bank.

Aturan yang dikenakan kepada nasabah dalam murabahah ini dalam fatwa adalah sebagai berikut:

a. Nasabah mengajukan permohonan dan perjanjian pembelian suatu barang atau asset kepada bank.

b. Jika bank menerima permohonan tersebut ia harus membeli terlebih dahulu asset yang dipesannya secara sah dengan pedagang.

c. Bank kemudian menawarkan asset tersebut kepada nasabah dan nasabah harus menerima (membeli)nya sesuai dengan perjanjian yang telah disepakatinya, karena secara hukum perjanjian tersebut mengikat kemudian kedua belah pihak harus membuat kontak jual beli.

d. Dalam jual beli ini bank dibolehkan meminta nasabah untuk membayar uang muka saat menandatangani kesepakatan awal pemesanan.

e. Jika nasabah kemudian menolak membeli barang tersebut, biaya riil bank harus dibayar dari uang muka tersebut.

f. Jika nilai uang muka kurang dari kerugian yang harus ditanggung oleh bank, bank dapat meminta kembali sisa kerugiannya kepada nasabah.

g. Jika uang muka memakai kontrak 'urbun sebagai alternatif dari uang muka, maka : (1) jika nasabah memutuskan untuk membeli barang tersebut, ia tinggal membayar sisa harga; atau (2) jika nasabah batal membeli, uang muka menjadi milik bank maksimal sebesar kerugian yang ditanggung oleh bank akibat pembatalan tersebut; dan jika uang muka tidak mencukupi, nasabah wajib melunasi kekuranganya.

h. Jaminan dalam murabahah diperbolehkan, agar nasabah serius dengan pesananya. Disini bank dapat meminta nasabah untuk menyediakan jaminan yang dapat dipegang.

i. Hutang dalam murabahah secara prinsip penyelesaianya tidak ada kaitanya dengan transaksi lain yang dilakukan nasabah dengan pihak ketiga atas barang tersebut. Jika nasabah menjual kembali barang tersebut sebelum masa angsuran berakhir, ia tidak wajib 
segera melunasi seluruh angsurannya. Kemudian jika penjualan barang tersebut menyebabkan kerugian, nasabah harus tetap menyelesaikan hutangnya sesuai kesepakatan awal. Ia tidak boleh memperlambat pembayaran angsuran atau meminta kerugian itu diperhitungkan.

5) Rukun dan Syarat Murabahah (Hakim, 2012).

a. Rukun Murabahah

Karena murabahah termasuk dalam kategori jual beli maka rukunnya adalah rukun jual beli yaitu: penjual, pembeli, barang, harga, ijab dan qobul. Apabila salah satu rukun ini tidak terdapat maka murabahah tidak sah hukumnya.

b. Syarat Murabahah

Sebagaimana rukun, syarat juga menentukan sah tidaknya sebuah transaksi. Adapun syarat murabahah, yaitu para ulama telah berijma bahwa:

a) Informasi mengenai harga awal/pokok.

b) Informasi tentang keuntungan.

c) Media pembayaran harus unit hitung.

d) Tidak boleh mengandung riba.

e) Akad pembelian yang pertama harus sah.

6) Jenis-jenis Murabahah

a. Murabahah dengan cicilan, yaitu harga jual dicantumkan dalam akad jual beli dan jika telah disepakati tidak dapat berubah selama berlakunya akad. Serta bila sudah ada barang maka segera akan diserahkan secara tangguh atau cicilan.

b. Murabahah dengan tunai yaitu bank bertindak sebagai penjual sementara nasabah sebagai pembeli. Harga jual adalah harga beli bank dari produsen ditambah keuntungan. Kedua pihak harus menyepakati harga jual dan dilakukan pembayaranya dengan tunai.

7) Tipe penerapan murabahah

a) Tipe pertama

Tipe pertama pembiayaan murabahah adalah tipe konsisten terhadap fiqih muamalah. Menurut tipe ini bank membeli dahulu barang yang akan dibeli oleh nasabah setelah ada perjanjian sebelumnya.

b) Tipe kedua

Tipe kedua mirip dengan tipe pertama, tetapi perpindahan kepemilikan langsung dari supplier kepada nasabah, sedangkan pembayaran dilakukan bank langsung kepada penjual supplier.

c) Tipe ketiga

Tipe ketiga ini yang paling banyak dipraktekkan oleh bank syariah. Bank melakukan perjanjian murabahah dengan nasabah dan pada saat yang sama mewakilkan (akad wakalah) kepada nasabah untuk membeli sendiri barang yang akan dibelinya. Dana lalu dikredit ke rekening nasabah dan nasabah menandatangani 
tanda terima uang. Dalam penelitian ini pembiayaan murabahah yang berikan adalah tipe ketiga.

8) Kelebihan Murabahah (Ashari, 2014).

a. Nasabah mengetahui semua biaya yang semestinya serta mengetahui harga pokok barang dan keuntungan (margin) dari bank.

b. Pembayaran dapat dilakukan secara tunai atau diangsur (cicilan).

c. Jumlah angsuran yang tidak akan berubah selama akad selesai.

d. Adanya keringanan atau potongan jika terjadi macet namun hanya terbatas pada margin.

9) Resiko Pembiayaan Murabahah

a. Resiko pembiayaan (credit risk), yang disebabkan oleh nasabah wanprestasi atau gagal dalam mengembalikan pembiayaan yang diterima dari bank (default).

b. Resiko pasar, yang disebabkan oleh pergerakan nilai tukar, jika pembiayaan atas dasar akad murabahah di berikan dalam valuta asing (Purnamasari, 2001).

2. Kesejahteraan Nasabah

Menurut Sudarman Danim manusia yang sejahtera adalah manusia yang memiliki tata kehidupan dan penghidupan baik material maupun spiritual yang disertai dengan rasa keselamatan, kesusilaan dan ketentraman lahir dan batin yang pada akhirnya dapat memenuhi kebutuhan jasmaniah, rohaniah dan sosialnya (Danim, 1995) Sedangkan teori kesejahteraan sosial dan ekonomi adalah sebagai berikut:

Ekonomi Italia, Vilveredo Pareto, telah menspesifikasikan suatu kondisi atau syarat terciptanya alokasi sumber daya secara efisien atau optimal, yang kemudian terkenal dengan istilah syarat atau kondisi pareto (Pareto Condition). Kondisi pareto adalah suatu alokasi barang sedemikian rupa, sehingga bila dibandingkan dengan alokasi lainnya, alokasi tersebut tak akan merugikan pihak manapun dan salah satu pihak pasti diuntungkan. Atas kondisi pareto juga bisa didefinisikan sebagai suatu situasi dimana sebagian atau semua pihak individu takan mungkin lagi diuntungkan oleh pertukaran sukarela.

Berdasarkan kondisi pareto inilah, kesejahteraan sosial diartikan sebagai kelanjutan pemikiran yang lebih utama dari konsep-konsep tentang kemakmuran (walfare economics), (Swasono, 2005:2). Boulding dalam Swasono mengatakan bahwa pendekatan yang memperkukuh konsepsi yang telah dikenal sebagai sosial optimum yaitu paretion optimum dimana efesiensi ekonomi mencapai sosial optimum bila tidak seorangpun bisa lagi menjadi lebih beruntung. bahwa kesenangan atau kepuasan seseorang dapat diukur dan bertambah.

Dari beberapa pengertian diatas dapat disimpulkan bahwa tingkat kesejahteraan seseorang dapat terkait dengan tingkat kepuasan (utility) dan kesenangan (pleasure) yang dapat diraih dalam kehidupannya guna mencapai tingkat kesejahteraannya yang diinginkan. Maka dibutuhkan suatu prilaku yang dapat memaksimalkan tingkat kepuasa sesuai dengan sumberdaya yang tersedia. 
Kesejahteraan hidup seseorang dalam realitanya, memiliki banyak indicator keberhasilan yang dapat diukur. Dalam hal ini Thomas dkk. (2005:15) menyampaikan bahwa kesejahteraan masyarakat menengah ke bawah dapat di representasikan dari tingkat hidup masyarakat ditandai oleh terentaskannya kemiskinan, tingkat kesehatan yang lebih baik, perolehan tingkat pendidikan yang lebih tinggi, dan peningkatan produktivitas masyarakat. Kesemuanya itu merupakan cerminan dari peningkatan tingkat pendapatan masyarakat golongan menengah kebawah.

Todaro secara lebih spesifik mengemukakan bahwa fungsi kesejahteraan W (walfare) dengan persamaan sebagai berikut :

$\mathrm{W}=\mathrm{W}(\mathrm{Y}, \mathrm{I}, \mathrm{P})$

Dimana $\mathrm{Y}$ adalah pendapatan perkaital I adalah ketimpangan, dan $\mathrm{P}$ adalah kemiskinan absolute. Ketiga variabel ini mempunyai signifikan yang berbeda-beda, dan selayaknya harus dipertimbangkan secara menyeluruh untuk menilai kesejahteraan di Negara-negara berkembang. Berkaitan dengan fungsi persamaan kesejahteraan diatas, diasumsikan bahwa kesejahteraan sosial berhubungan positif dengan pendapatan perkapital, namun berhubungan negatif dengan kemiskinan.

Dalam mengukur kesejahteraan nasabah, ada beberapa tahapan keluarga sejahtera yaitu (BKKBN, 2000).

a. Keluarga pra sejahtera yaitu keluarga yang belum dapat memenuhi kebutuhan dasar secara minimal seperti: kebutuhan spiritual, pangan, sandang, papan dan kesehatan atau keluarga yang belum dapat memenuhi salah satu indikator-indikator keluarga sejahtera I.

b. Keluarga sejahtera I yaitu keluarga yang telah dapat memenuhi kebutuhan dasarnya secara minimal tetapi belum dapat memenuhi keseluruhan kebutuhan social psikologisnya seperti : kebutuhan akan pendidikan, keluarga berencana, interaksi dalam keluarga, interaksi dengan lingkungan sekitar dan transportasi.

c. Keluarga sejahtera II yaitu keluarga yang disamping dapat memenuhi kebutuhan dasarnya juga telah dapat memenuhi kebutuhan social psikolognya tetapi belum dapat memenuhi kebutuhan pengembangan seperti: menabung dan memperoleh informasi.

d. Keluarga sejahtera III yaitu keluarga yang telah dapat memenuhi keseluruhan kebutuhan dasar, kebutuhan sosial, psikologisnya dan kebutuhan pengembangan tetapi belum dapat memberikan sumbangan yang maksimal dan teratur bagi masyarakat dalam bentuk material, seperti: sumbangan materi untuk kepentingan sosial kemasyarakatan atau yayasan sosial, keagamaan, kesenian, olah raga, pendidikan.

e. Keluarga sejahtera III plus yaitu keluarga yang telah dapat memenuhi seluruh kebutuhannya baik yang bersifat dasar, sosial psikologis maupun pengembangan serta telah memberikan sumbangan yang nyata dan berkelanjutan bagi masyarakat.

3. Kesejahteraan dalam Perspektif Al qur'an dan Hadist

Islam datang sebagai agama terakhir yang bertujuan untuk mengantarkan pemeluknya menuju kepada kebahagiaan hidup yang hakiki, oleh karena itu islam sangat memperhatikan kebahagiaan manusia baik itu kebahagiaan dunia maupun akhirat, dengan kata lain islam (dengan segala 
aturan) sangat mengharapkan umat manusia untuk memperoleh kesejahteraan materi dan spiritual.

Al Qur'an juga menyinggung tentang kesejahteraan yang terdapat pada surat An Nahl ayat 97

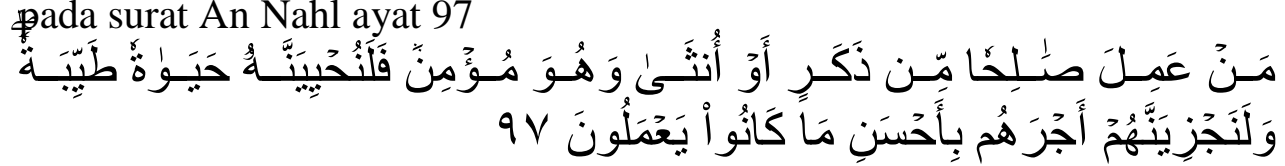

"Barangsiapa yang mengerjakan amal saleh, baik laki-laki maupun perempuan dalam keadaan beriman, maka sesungguhnya akan Kami berikan kepadanya kehidupan yang baik dan sesungguhnya akan Kami beri balasan kepada mereka dengan pahala yang lebih baik dari apa yang telah mereka kerjakan. "'(Al Qur'an Surat An Nahl ayat 97)

Berdasarkan pada surat An Nahl ayat 97, kita dapat menyimpulkan bahwa kesejahteraan dapat diperoleh bagi siapa saja yang mau melakukan kebaikan, tanpa memandang laki-laki atau perempuan, juga tidak memandang bentuk fisik seseorang, apakah berkulit putih atau hitam, tampan atau cantik, orang arab atau orang 'Ajam (non arab), keturunan ulama atau bukan semuanya sama.

Secara keseluruhan dari teori kesejahteraan, tahapan keluarga sejahtera dan landasan Al Qur'an diatas dapat diambil kesimpulan bahwa kesejahteraan adalah suatu tata kehidupan dan penghidupan baik material maupun spiritual disertai dengan rasa keselamatan, kesusilaan dan ketentraman lahir dan batin yang pada akhirnya dapat memenuhi kebutuhan jasmaniah, rohaniah dan sosial. Kesejahteraan yang dimaksud dalam penelitian ini adalah terkait dengan kesejahteraan nasabah sebelum dan sesudah melakukan pembiayaan murabahah di BTPN Syariah.

\section{A. Kerangka Berpikir}

Untuk mendukung materi dalam penelitian ini, penulis membandingkan dengan beberapa penelitian yang terdahulu, diantaranya:

1. Skripsi tahun 2016 dengan judul "PELAKSANAAN PEMBIAYAAN MURABAHAH BERDASARKAN PRINSIP HUKUM EKONOMI SYARIAH" di Bank Muamalat cabang Bandar Lampung, disusun oleh M Haris Fikri. Hasil dari penelitian tersebut menyatakan bahwa akad murabahah pada Bank Muamalat Cabang Bandar Lampung menggunakan akad wakalah yaitu memberikan kuasa kepada nasabah untuk membeli obyek atau barang yang telah disepakati dalam akad, pelaksanaan akad murabahah dengan akad wakalah pada Bank Muamalat Cabang Bandar Lampung tidak bertentangan dengan ketentuan yang ada.

2. Skripsi tahun 2009 dengan judul "IMPLEMENTASI AKAD MURABAHAH DALAM PEMBIAYAAN RUMAH BERSUBSIDI SECARA SYARIAH DI BANK TABUNGAN NEGARA KANTOR CABANG SYARIAH SURAKARTA" disusun oleh Abdul Azziz Herawanto. Berdasakan penelitian yang telah penulis lakukan, proeses implementasi akad murabahah dalam pembiayaan pemilikan rumah bersubsidi secara syariah di Bank Tabungan Negara Kantor Cabang Syariah Surakarta sudah menerapkan prinsip-prinsip syariah islam.

3. Skripsi tahun 2012 dengan judul "PELAKSANAAN AKAD MURABAHAH UNTUK PEMBIAYAAN MODAL USAHA" pada PT BPRS Margirizki Bahagia Yogyakarta, disusun oleh Alfian. Berdasarkan 
penelitian yang telah penulis lakukan, terdapat solusi untuk memperbaiki pelaksanaan akad murabahah tersebut supaya sesuai dengan syariah yaitu melalui aspek pelaksanaan dan aspek pengawasan.

Secara sederhanan kerangka pemikiran yang penulis pergunakan dalam penyusunan penelitian dapat dilihat pada skema sebagai berikut:

Gambar 2.1

Keranga Pemikiran

\section{PEMBIAYAAN MURABAHAH}

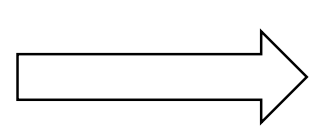

KESEJAHTERAAN NASABAH

Dari kerangka pemikiran diatas dapat kita ambil kesimpulan bahwa terdapat keterkaitan antara kesejahteraan nasabah dengan pembiayaan murabahah. Sehingga penulis perlu menganalisis tentang kesejahteraan nasabah sebelum dan sesudah melakukan pembiayaan murabahah.

\section{METODE PENELITIAN}

Peneliti ini menggunakan data kuantitatif dalam penelitianya. Sedangkan sumber data yang digunakan adalah data primer yakni menggunakan kuisoner sebelum memperoleh data.

\section{A. Tempat dan Waktu Penelitian}

Penelitian ini dilaksanakan di BTPN (Bank Tabungan Pensiunan Nasional) Syariah KFO Cikarang Barat Ruko Permata Junction Blok A No. 1 Kawasan Jababeka Jl. Raya Industri Cikarang-Bekasi pada tanggal $10 \mathrm{Juli}$ s/d 15 Agustus 2017.

Pada penelitian ini dapat didefisinikan dari masing-masing variabel adalah sebagai berikut:

1) Variabel bebas $(X)=$ Pembiayaan Murabahah

Pembiayaan murabahah adalah suatu produk atau layanan dari perbankan syariah yang memberikan dana talangan kepada nasabah.

2) Variabel terikat $(Y)=$ Kesejahteraan Nasabah

Kesejahteraan nasabah adalah suatu aspek yang sangat penting dalam tatanan kehidupan masyarakat atau nasabah.

\section{B. Populasi dan Sampel}

1. Populasi

Populasi adalah wilayah generalisasi yang terdiri atas obyek atau subyek yang mempunyai kualitas dan karakteristik tertentu yang ditetapkan oleh peneliti untuk dipelajari dan kemudian ditarik kesimpulanya. ${ }^{5}$ Populasi dalam penelitian ini adalah seluruh nasabah di BTPN Syariah KFO Cikarang Barat yaitu berjumlah 14.000 nasabah. ${ }^{6}$

2. Sampel

Sampel adalah suatu bagian dari jumlah dan karakteristik yang dimiliki oleh populasi tertentu. Bila populasi besar, dan peneliti tidak

\footnotetext{
${ }^{5}$ Sugiyono, Metode Penelitian Administrasi, Bandung : Alfabeta, 2003, h. 90

${ }^{6}$ Hasil Wawancara Pegawai BTPN Syariah KFO Cikarang Barat
} 
mungkin mempelajari semua yang ada dalam populasi, maka peneliti dapat menggunakan sampel yang diambil dari populasi itu. ${ }^{7}$

Secara umum, teknik pengambilan sampel atau teknik sampling dapat dikelompokan menjadi dua yaitu probability sampling dan nonprobability sampling. Probability sampling adalah teknik pengambilan sampel yang memberikan peluang yang sama bagi setiap unsur (anggota) populasi untuk dipilih menjadi anggota sampel. Sedangkan nonprobability sampling adalah teknik pengambilan sampel yang tidak memberi peluang atau kesempatan sama bagi setiap unsur atau anggota populasi untuk dipilih menjadi sampel. ${ }^{8}$

Roscoe dalam buku Research Methods For Business (1982:253) memberikan saran-saran tentang ukuran sampel untuk penelitian sebagai berikut ini: ${ }^{9}$

a. Ukuran sampel yang layak dalam penelitian adalah antara 30 sampai dengan 500.

b. Bila sampel dibagi dalam kategori (misalnya: pria-wanita, pegawai negeri-swasta dan lain-lain) maka jumlah anggota sempel setiap kategori minimal 30.

c. Bila dalam penelitian akan melakukan analisis dengan multivatiate (korelasi atau regresi ganda misalnya), maka jumlah anggota sampel minimal 10 kali dari jumlah variabel yang diteliti. Misalnya variabel penelitiannya ada 5 (independen + dependen), maka jumlah anggota sampel $=10 \times 5=50$.

d. Untuk penelitian eksperimen yang sederhana, yang menggunakan kelompok kontrol, maka jumlah anggota sampel masing-masing antara $10 \mathrm{~s} / \mathrm{d} 20$.

Untuk menentukan sampel dapat menggunakan rumus slovin, yaitu sebagai berikut: ${ }^{10}$

$n=\frac{N}{1+N\left(e^{2}\right)}$

Keterangan:

$n=$ ukuran sampel

$\mathrm{N}=$ populasi

$\mathrm{e}=$ preosentasi kelonggaran ketidakterikatan karena kesalahan pengambilan sampel yang masih diinginkan, pada kasus ini menggunakan e $=5 \%(0,05)$

Misalkan jumlah populasinya adalah 14.000 nasabah, dan tingkat kesalahan yang dikehendaki adalah 5\%, maka jumlah sampel yang digunakan adalah :

$n=\frac{N}{1+N\left(e^{2}\right)}=\frac{14000}{1+14000\left(0,05^{2}\right)}=388,88$ atau dibulatkan menjadi 389 responden.

Jadi sampel penelitian untuk populasi 14000 nasabah dan tingkat kesalahan yang dikehendaki 5\% adalah 389 nasabah.

\footnotetext{
${ }^{7}$ Sugiyono, Metode Penelitian Administrasi...., h. 91

8 ibid h $92-95$

9 ibid $102-103$

${ }^{10}$ V. Wiratna Sujarweni, Metodelogi Penelitian, Yogyakarta: Pustaka Baru Press, 2014, h. 66
} 


\section{Teknik Pengambilan Data}

Data atau bahan keterangan ialah fakta yang dapat ditarik menjadi suatu kesimpulan dalam kerangka persoalan yang digarap. Fakta ialah kenyataan yang telah didudukkan dalam kerangka persoalan. Pengertian kenyataan mencakup segala sesuatu kebenaran umum dan bersifat mantap (Notohadiprawiro,2006). ${ }^{11}$

1. Kuesioner

Kuesioner adalah cara pengumpulan data dengan menggunakan pertanyaan-pertanyaan tertulis untuk memperoleh informasi dari responden. Ada beberapa cara yang dapat dilakukan untuk mengumpulkan data melalui kuesioner, yaitu:

a) Mengirimkan kuesioner kepada responden

b) Dikirim dengan pos (metode ini kurang efektif)

c) Datang langsung ke lokasi sehingga peneliti dapat memberi petunjuk pengisian

d) Metode setengah wawancara (kuesioner dipegang oleh peneliti dan responden hanya menjawab pertanyaan yang diajukan, lalu peneliti yang mencatatnya). ${ }^{12}$

Berikut adalah kis-kisi instrument kuesioner dalam penelitian ini:

Tabel 3.2

Instrumen Kuisoner

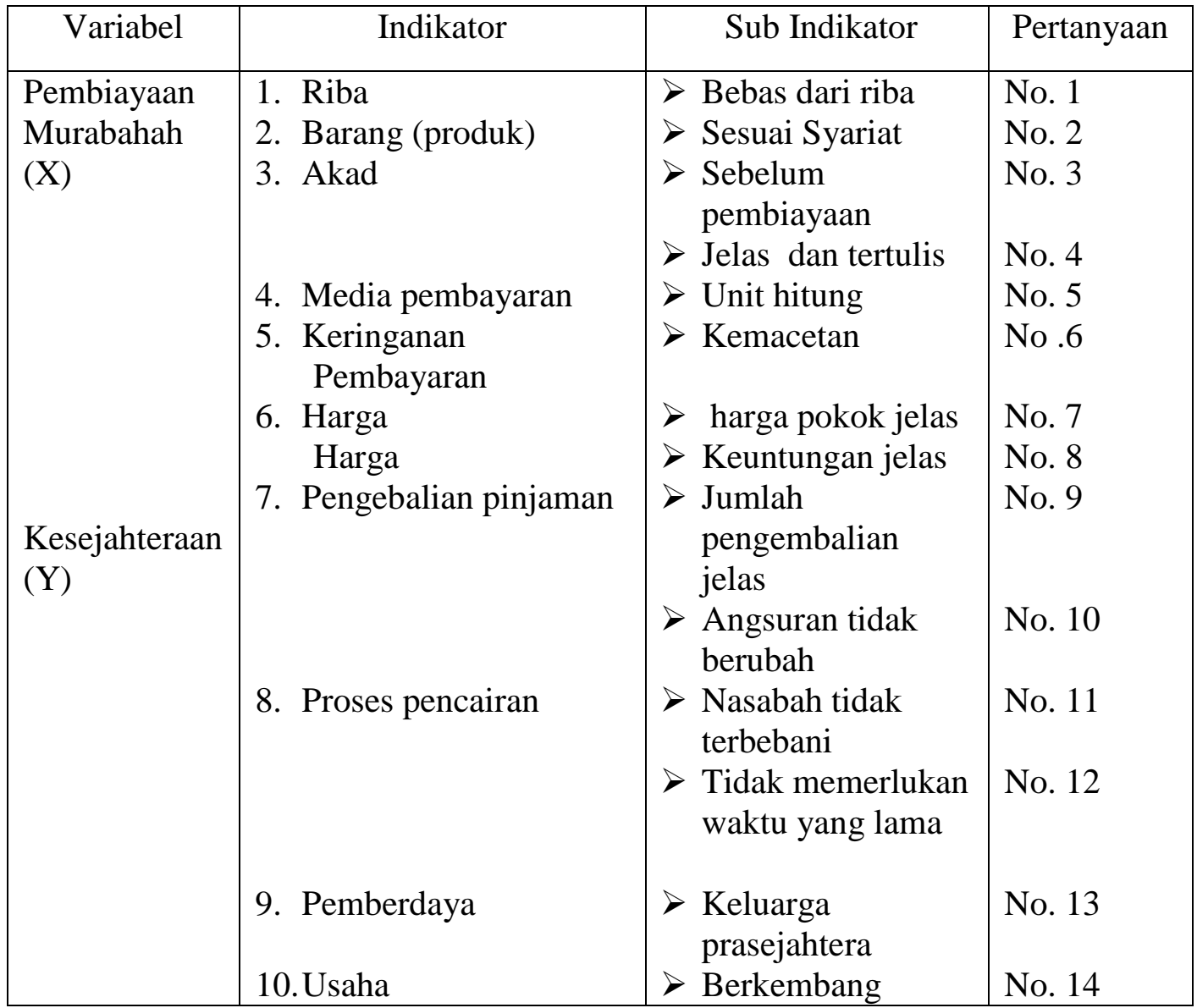

\footnotetext{
${ }^{11}$ Hendri Tanjung dan Abrista Devi, Metodologi penelitian Ekonomi Islam...., h. 76

12 Ibid, hal 79-80
} 


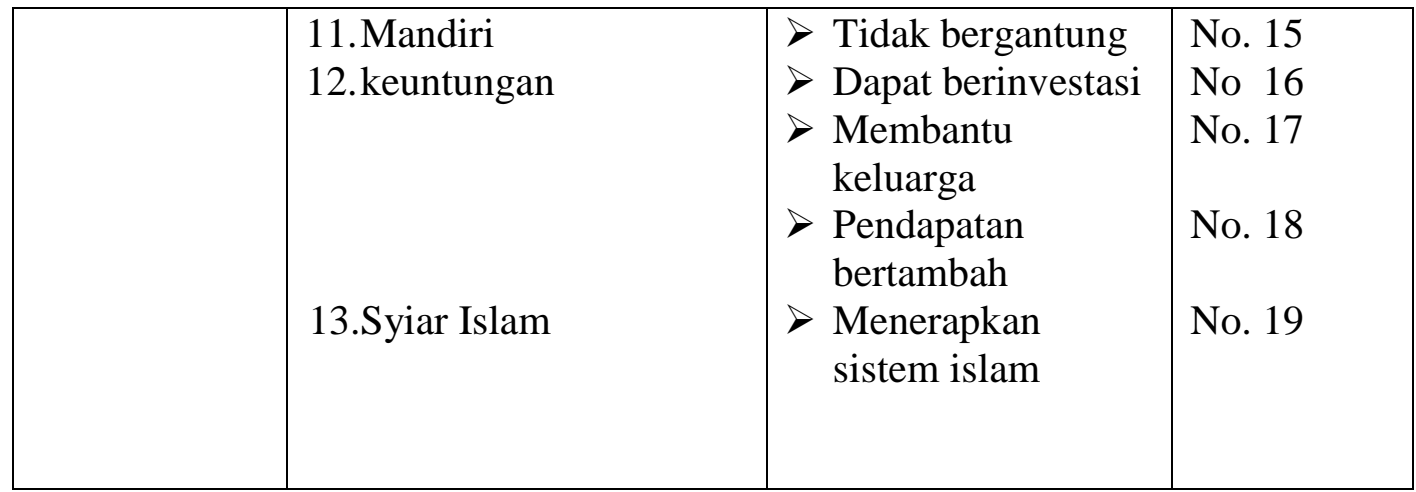

2. Wawancara

Pada penelitian ini, peneliti selain melakukan kuisoner kepada nasabah juga melakukan wawancara kepada pegawai dan juga kepada nasabah BTPN Syariah KFO Cikarang Barat.

\section{Metode Analisis}

Dalam penelitian ini metode analisis data yang digunakan adalah analisis kuantitatif. Analisis kuantitatif digunakan untuk menguji hipotesis. Dalam penelitian ini analisis kuantitatif diperhitungkan menggunakan SPSS Versi 16. Berikut ini langkah-langkah yang digunakan sebelum data dianalisis:

a. Uji Instrumen

1) Uji Validitas

2) Uji Reliabititas

b. Pengujian Hipotesis Koefisien Regresi

1) Pengujian Secara (uji t)

2) Uji Koefisien Regresi Secara Simultan (Uji F)

3) Uji Koefisiens Determinasi $\left(R^{2}\right)$

\section{HASIL PENELITIAN DAN PEMBAHASAN}

Dalam penelitian ini, peneliti hanya terfokus pada pembiayaan murabahah yang ada di dalam produk paket masa depan tentang ada tidaknya pengaruh pembiayaan murabahah dalam mensejahterakan nasabah. Sedangkan data yang diperoleh setelah menyebarkan 389 kuisoner kepada nasabah, ternyata data yang kembali hanya 100. Hal ini, disebabkan karena kurangnya rasa kepedulian nasabah untuk mengembalikan data kepada peneliti. Sehingga peneliti hanya bisa mengolah data sebanyak 100 yang kemudian diolah menggunakan SPSS versi 16.

Sebelum menjabarkan tentang analisi data dalam perhitungan dengan menggunakan bantuan program SPSS, sebagaimana telah diketahui hipotesis penelitian ini adalah :

$\mathrm{H}_{0}=$ Pembiayaan murahabah tidak dapat mempengaruhi kesejahteraan nasabah.

$\mathrm{H}_{\mathrm{a}}=$ Pembiayaan murabahah dapat mempengaruhi kesejahteraan nasabah.

1) Koefisien Korelasi

Tabel 4.8 
Pengujian Koefisien Korelasi

\begin{tabular}{|c|c|c|c|c|}
\hline & & Correlations & & \\
\hline & & & $\begin{array}{l}\text { kesejahteraan } \\
\text { nasabah }\end{array}$ & $\begin{array}{l}\text { pembiayaan } \\
\text { murabahah }\end{array}$ \\
\hline & Pearson Correlation & $\begin{array}{l}\text { kesejahteraan nasabah } \\
\text { pembiayaan murabahah }\end{array}$ & $\begin{array}{r}1.000 \\
.089 \\
\end{array}$ & $\begin{array}{r}.089 \\
1.000 \\
\end{array}$ \\
\hline & Sig. (1-tailed) & $\begin{array}{l}\text { kesejahteraan nasabah } \\
\text { pembiayaan murabahah }\end{array}$ & .190 & .190 \\
\hline Sumber & $\mathrm{N}$ & $\begin{array}{l}\text { kesejahteraan nasabah } \\
\text { pembiayaan murabahah }\end{array}$ & $\begin{array}{l}100 \\
100\end{array}$ & $\begin{array}{l}100 \\
100\end{array}$ \\
\hline
\end{tabular}

SPSS

\section{Versi 16. Data diolah}

Berdasarkan tabel 4.8 diketahui bahwa hasil nilai korelasi variabel X dan Y yang diperoleh nilai sig 0,190 dan lebih besar dari nilai sig yaitu 0.05 . Artinya tidak terdapat hubungan antara variabel pembiayaan murabahah terhadap kesejahteraan nasabah.

2) Uji Koefisien Determinan $\left(R^{2}\right)$

\section{Tabel 4.9}

Hasil Koefisien Determinasi $\left(R^{2}\right)$

\begin{tabular}{|c|c|c|c|c|}
\hline \multicolumn{5}{|c|}{ Model Summary ${ }^{b}$} \\
\hline Model & $\mathrm{R}$ & R Square & Adjusted R Square & $\begin{array}{l}\text { Std. Error of the } \\
\text { Estimate }\end{array}$ \\
\hline 1 & $.089^{\mathrm{a}}$ & .008 & -.002 & 1.933 \\
\hline
\end{tabular}

Berdasarkan tebel 4.9 diketahui bahwa nilai $\mathrm{R}$ square atau koefisien determinan $\left(R^{2}\right)$ menujukan nilai 0,008. Sehingga dapat ditafsirkan bahwa variabel $\mathrm{X}$ (pembiayaan murabahah) memiliki pengaruh kontribusi sebesar 0,8\% terhadap kesejahteraan nasabah (Y). Sehingga sisanya sebesar 99,2\% dipengaruhi oleh faktor lain.

3) Pengujian Secara (Uji T)

Tabel 4.10

Hasil Uji T

Coefficients $^{\mathrm{a}}$

\begin{tabular}{|c|c|c|c|c|c|}
\hline \multirow[b]{2}{*}{ Model } & \multicolumn{2}{|c|}{ Unstandardized Coefficients } & $\begin{array}{l}\text { Standardized } \\
\text { Coefficients }\end{array}$ & \multirow[b]{2}{*}{$\mathrm{T}$} & \multirow[b]{2}{*}{ Sig. } \\
\hline & $\mathrm{B}$ & Std. Error & Beta & & \\
\hline $1 \quad$ (Constant $)$ & 24.327 & 3.071 & & 7.921 & .000 \\
\hline $\begin{array}{l}\text { Pembiayaan } \\
\text { Murabahah }\end{array}$ & .053 & .060 & .089 & .882 & .380 \\
\hline
\end{tabular}

a. Dependent Variable: Kesejahteraan Nasabah Sumber : Output SPSS Versi 16. Data diolah 
erdasarkan tabel 4.10 diketahui bahwa nilai koefisien konstanta adalah 24,327 koefisien variabel bebas (X) adalah sebesar 0,53 sehingga diperoleh persamaan regresi linier sederhana adalah:

$\mathrm{Y}=24,327+0,53 \mathrm{X}$.

Secara sistematis nilai konstanta 24,327 menyatakan bahwa pada saat pembiayaan murabahah 0 , maka nilai kesejahteraan nasabah 24,327. Jadi jika terdapat kenaikan pada nilai pembiayaan murabahah maka nilai kesejahteraan nasabah akan bertambah, namun jika ada pengurangan nilai pembiayaan murabahah maka nilai kesejahteraan nasabah akan berkurang.

Dari tabel 4.10 juga telihat bahwa nilai t hitung sebesar 0,882 dengan nilai sig $=0,380$ sedangkan $t$ tabel memperoleh nilai 1,984 untuk $\mathrm{df}=98(\mathrm{df}=100-2)$. Hal tersebut menunjukan $\mathrm{t}$ hitung $<\mathrm{t}$ tabel yang berarti pembiayaan murabahah tidak mempengaruhi kesejahteraan nasabah.

4) Pengujian Secara Simultan (Uji F)

Tabel 4.11

Hasil Uji F

ANOVA $^{b}$

\begin{tabular}{|ll|r|r|r|r|r|}
\hline Model & Sum of Squares & Df & Mean Square & F & Sig. \\
\hline 1 & Regression & 2.906 & 1 & 2.906 & .778 & $.380^{\mathrm{a}}$ \\
& Residual & 366.004 & 98 & 3.735 & & \\
& Total & 368.910 & 99 & & & \\
\hline
\end{tabular}

a. Predictors: (Constant), Pembiayaan Murabahah

b. Dependent Variabel : Kesejahteraan Nasabah

Sumber : Output SPSS Versi 16. Data diolah

\section{b. Pembahasan}

dasarkan tabel 4.11 diperoleh nilai $\mathrm{F}$ hitung $=0,778$ dengan nilai sig $=$ 0,380 dan nilai $\mathrm{F}$ tabel $=3,94$. Sehingga dapat diambil kesimpulan bahwa $\mathrm{F}$ hitung $<\mathrm{F}$ tabel dan nilai probabilitas atau sig lebih besar dari 0,05 . Artinya hasil uji $F$ juga menunjukan bahwa pembiayaan murabahah tidak mempengaruhi kesejahteraan nasabah.

Hasil penelitian menujukan sumbangan efektif pembiayaan murabahah terhadap kesejahteraan nasabah adalah $0,8 \%$. Hasil uji t memperoleh nilai $t$ hitung $=0,882$ dan $\mathrm{t}$ tabel $=1,984$ dengan nilai sig $=0,380$ dan uji $\mathrm{f}$ memperoleh nilai $\mathrm{f}$ hitung $=0,778$ dan $\mathrm{f}$ tabel $=3,94$ dengan nilai sig 0,380. Jadi nilai $\mathrm{t}$ hitung $<\mathrm{t}$ tabel dan $\mathrm{f}$ hitung $<\mathrm{f}$ tabel, artinya pada penelitian ini tidak ada pengaruh pembiayaan murabahah terhadap kesejahteraan nasabah. Sehingga dapat diambil kesimpulan $\mathrm{H}_{0}$ yaitu pembiayaan murabahah tidak dapat mempengaruhi kesejahteraan nasabah diterima dan $\mathrm{H}_{\mathrm{a}}$ yaitu pembiayaan murabahah dapat mempengaruhi kesejahteraan nasabah ditolak.

Hasil penelitian menujukan bahwa pembiayaan murabahah di lakukan menggunakan akad wakalah wal murabahah yaitu mewakilkan nasabah dalam hal pembelian barang. Hal ini sebenarnya menguntungkan bagi pihak perbankkan namun dengan mewakilkan pembelian barang memiliki resiko 
penggunaan pembiayaan tidak sesuai dengan akad dan hal ini yang akan berpengaruh terhadap usaha nasabah.

Hasil wawancara juga menunjukan bahwa pembiayaan murabahah tidak $100 \%$ digunakan untuk modal usaha melainkan banyak yang digunakan untuk kebutuhan sehari-hari seperti untuk biaya sekolah, belanja dapur dan kebutuhan lainya. Hal inilah yang menyebabkan nasabah tidak mampu membayar pinjaman karena penggunaan pinjaman atau talangan dana tidak sesuai tempatnya. Jadi pembiayaan murabahah yang diberikan oleh pihak bank kepada nasabah tidak mempengaruhi kesejahteraan nasabah.

\section{KESIMPULAN}

Berdasarkan hasil penelitian dan analisis data yang didapat pada "Pengaruh Pembiayaan Murabahah Terhadap Kesejahteraan Nasabah" dapat ditarik beberapa kesimpulan sebagai berikut:

1. Dalam penelitian ini, pembiayaan murabahah hanya mempengaruhi $0,8 \%$ terhadap kesejahteraan nasabah dan 99,2\% dipengaruhi dari faktor lain. Sehingga bisa diambil kesimpulan pembiayaan murabahah tidak berpengaruh terhadap kesejahteraan nasabah.

2. Pembiayaan murabahah yang diberikan tidak mempengaruhi kesejahteraan nasabah dikarenakan adanya faktor penyalahguaan akad yaitu nasabah menggunakan pembiayaan murabahah tidak untuk modal usaha melainkan untuk memenuhi kebutuhan sehari-hari seperti biaya sekolah, belanja dapur dan kebutuhan lainya.

3. Penyalahgunaan akad berpengaruh negatif terhadap pembiayaan murabahah yang diberikan. Sehingga pembiayaan murabahah tidak dapat mempengaruhi kesejahteraan nasabah.

Setelah penulis menganalisis variabel pembiayaan murabahah dan kesejahteraan nasabah maka penulis memberikan saran agar pembiayaan murabahah bisa atau mampu mensejahterakan nasabah yaitu sebagai berikut:

1. Berdasarkan kesimpulan hasil penelitian dapat diketahui bahwa penyalahgunaan akad berpengaruh negatif terhadap pembiayaan murabahah maka seharusnya pihak bank lebih teliti lagi dalam memberikan pembiayaan murabahah dengan meningkatkan standarstandar atau karakteristik nasabah.

2. Sebelum memberikan pinjaman pihak bank harus memberikan pengetahuan lebih dalam lagi tentang fungsi pembiayaan murabahah yaitu hanya diperuntukan untuk modal usaha.

3. Setelah melakukan akad pihak bank seharusnya melakukan survey lebih dalam lagi tentang usaha nasabah. Apakah pembiayaan murabahah digunakan untuk usaha atau tidak dan apabila tidak maka pihak bank harus meyakinkan kembali nasabah untuk menggunakan pinjaman atau pembiayaan untuk usaha.

4. Selain meningkatkan standar-standar dan karakteristik nasabah, pihak bank juga harus menyediakan karyawan dan pegawai yang kompeten atau sesuai dengan kemampuanya sehingga pengetahuan tentang 
pembiayaan murabahah tersalurkan dengan baik kepada nasabah dan hal ini bisa meminimalkan terjadinya penyalahgunaan akad.

5. Mengganti tipe murabahah yaitu pembelian barang yang diwakilkan kepada nasabah menjadi pembelian barang dilakukan oleh pihak bank bisa menjadi solusi untuk meminimalkan terjadinya penyalahgunaan akad.

\section{REFERENSI}

Amirus Sodik, "Konsep Kesejahteraan dalam Islam", Jurnal Ekonomi Syariah, Vol. 3, No 2, Desember 2015.

Antonio, Muhammad Syafii, Bank Syariah; Dari Teori ke Praktik, Jakarta : Gema Insani, 2001.

Anwar, M Syafii, Alternatif Terhadap Sistem Bunga, Jurnal Ulumul Qur'an II, edisi 9 Oktober 1991.

Arikunto, Suharsini, Prosedur Penelitian Suatu Pendekatan Praktek, Jakarta : Rineka Cipta, 2002

BKKBN, Pendataan Keluarga Tahun 2000, http://www.bkkbn.go.id/privince/yogya/MENU 04.html (09 Agustus 2017)

BTPN Syariah [Online], http://www.btpnsyariah.com Html (24 Agustus 2017)

Danim, Sudarman, Transformasi Sumber Daya Manusia; Analisis Fungsi Pendidikan Dinamika Prilaku dan Kesejahteraan Manusia Indonesia Masa Depan Jakarta: Bumi Aksara, 1995.

Erwin Ashari, Akad Murabahah dalam Pembiayaan di Perbankan Syariah [Online], http://Duniameah.blogspot.com (9 Agustus 2017)

Eureka, Pendidikan [Online], www.eurekapendidikan.com Html (10 Agustus 2017).

Feedsia [Online], www.feedsia.com, Html (11 Agustus 2017)

Hakim, Cecep Maskanul, Belajar Mudah Ekonomi Islam, Tanggerang Selatan: Shahul Media Insani, 2011.

Hakim, Lukman, Prinsip-Prinsip Ekonomi Islam, Yogyakarta : Erlangga, 2012.

Hasil Wawancara Pegawai BTPN Syariah KFO Cikarang Barat 11 Juli 2017

Ibnu Suharwono dan Seno Andri, Pengaruh Media Iklan Terhadap Keputusan Pembelian Produk Perumahan PT. Astra Karya, JOM FISIP Vol 3 No. 1 Februari 2016.

Muthaher, Osmad, Akuntansi Perbankan Syariah, Yogyakarta : Graha Ilmu , 2012.

Natadipurba, Candra, Ekonomi Islam 101, Bandung : PT Mobildelta Indonesia, 2016.

Perwataatmadja, Karnaen A dan Hendri Tanjung, Bank Syariah ;Teori Praktek dan Penerapanya, Jakarta: Celestial Publising, 2007.

Pistaza [Online] http://pistaza.wordpress.com Html ( 09 Agustus 2017)

Purnamasari, Irma Devita, Akad Syariah, Bandung : Mizan Media Utama, 2001.

Rezqi Handayani, Variabel Penelitian dan Definisi Operasioanl [Online], www.umpalangkarya.ac.id Html (10 Agustus 2017)

Rivai, Veithzal dan Arviyan Arifin, Islamic Banking ; Sebuah Teori, konsep, dan Aplikasi, Jakarta: Bumi Aksara, 2010. 
Sholihin, Ahmad Ifham, Pedoman Umum Lembaga Keuangan Syariah, Jakarta : Gramedia Pustaka Utama, 2010.

Siboykasaci [online] https://siboykasaci.wordpress.com Html (11 Agustus 2017)

Sugiyono, Metode Penelitian Administrasi, Bandung : Alfabeta, 2003. . Metode Penelitian Kuantitatif, Kualitatif, $R \& D$, Bandung : Penerbit Alfabeta, 2009.

Sujarweni, V Wiratna, Metodelogi Penelitian, Yogyakarta: Pustaka Baru Press, 2014.

Syeed, Abdullah, Menyoal Bank Syariah ; Kritik atas Interprestasi Bunga Kaum Neorevivalitas, Jakarta: Paramadina, 2004.

Tanjung, Hendri dan Abrista Devi (Ed.), Metodelogi Penelitian Ekonomi Islam, Bekasi : Gramedia Publising, 2013.

UU Perbankan Syariah 2008, Jakarta :Sinar Grafika, 2008 